SILVA, GO; PEREIRA, AS; AZEVEDO, FQ; CARVALHO, ADF. 2018. Genotypic selection of advanced potato clones by REML/BLUP. Horticultura Brasileira 36: 265-270. DOI: http://dx.doi.org/10.1590/S0102-053620180220

\title{
Genotypic selection of advanced potato clones by REML/BLUP
}

\section{Giovani O Silva ${ }^{1}$; Arione S Pereira ${ }^{2}$; Fernanda Q Azevedo ${ }^{2}$; Agnaldo DF Carvalho $^{3}$}

${ }^{1}$ Embrapa Hortaliças-SPM, Canoinhas-SC, Brazil; giovani.olegario@embrapa.br; ${ }^{2}$ Embrapa Clima Temperado, Pelotas-RS, Brazil; arione. pereira@embrapa.br; fernanda.azevedo@embrapa.br; ${ }^{3}$ Embrapa Hortaliças, Brasília-DF, Brazil; agnaldo.carvalho@embrapa.br

\begin{abstract}
Potato genotypes were evaluated in their performance, according to the genotype values for tuber yield traits. The experiments were carried out in Canoinhas and Pelotas, Brazil, in spring 2014. Eleven advanced clones and two commercial cultivars (Agata and Asterix) (check cultivars) were evaluated. A randomized complete block design with four replicates was used. Plots were harvested 110 days after planting, and evaluated for tuber yield components. The data were submitted to joint deviance analyzes using the REML/BLUP method. Clones F102-22-07 and F32-02-06 stood out positively for tuber yield. F102-22-07 showed high marketable tuber yield and average tuber weight, while clone F32-02-06 exhibited high marketable and total tuber yield. The superiority of these advanced clones in relation to the check cultivars, suggests their potential to be evaluated in other environments, aiming their release as new cultivars.
\end{abstract}

Keywords: Solanum tuberosum, plant breeding, genotypic values.

\section{RESUMO} BLUP

Seleção genotípica de clones avançados de batata via REML/

Verificou-se o desempenho de genótipos de batata de acordo com os valores genotípicos para caracteres de rendimento de tubérculos. Os experimentos foram realizados em Canoinhas-SC e Pelotas-RS, na primavera de 2014. Foram avaliados onze clones e duas cultivares comerciais (Agata e Asterix) (testemunhas), em delineamento experimental em blocos casualizados com quatro repetições. A colheita foi realizada aos 110 dias após o plantio, seguida das avaliações de caracteres de componentes do rendimento de tubérculos. Analisou-se a deviance conjunta, por meio do método REML/BLUP. Os clones F102-22-07 e F32-02-06 destacaram-se positivamente para rendimento de tubérculos. O clone F102-22-07 apresenta alto rendimento de tubérculos comerciais e tubérculos de elevada massa média, enquanto o clone F32-02-06 apresenta elevado rendimento total e comercial de tubérculos. A superioridade destes clones avançados em relação às cultivares testemunhas, sugere potencial dos mesmos para serem avaliados em outros ambientes, visando o lançamento como novas cultivares.

Palavras-chave: Solanum tuberosum, melhoramento genético, valores genotípicos.

Received on March 21, 2017; accepted on February 2, 2018

$\mathrm{D}$ evelopment of Brazilian potato cultivars adapted to growing conditions of the country producing regions and with resistance to main diseases, is the most viable alternative to increase yield and profitability of this crop for growers (Gadum et al., 2003).

The main potato cultivars grown in Brazil are of European origin and, being not well adapted to the Brazilian environment (Kooman \& Rabbinge, 1996; Menezes et al., 2001; Pinto et al., 2010), show shorter vegetative cycle and lower yield, besides suffering greater pressure from pathogens and pests when grown here. To overcome these difficulties, high amounts of inputs are used to reach good yield, which reduce crop sustainability.
Plants, as well as other living organisms, are affected by the environment (E), genotype $(\mathrm{G})$ and their interaction (GE). The GE interaction promotes significant differences in genotype's performance when grown under different environmental conditions (Mohammadi et al., 2007). The GE interaction plays a key role in breeding programs, as it may interfere with the adaptability and stability of genotypes in relation to the tested environments.

According to Borges et al. (2010), inferences about genetic materials in field experiments, in order to identify those to be released as cultivars, should be based on true genotypic values, that is, on genotypic and non-phenotypic means. These estimates can be obtained using the best linear unbiased prediction (BLUP) and the restricted maximum likelihood (REML) methods. However, according to Resende (2002b), the REML procedure is equivalent to ANOVA in cases where the experiments are simple and balanced and meet the assumptions of the latter.

There are several traits to be considered for potato breeding. Among them is the tuber yield, essential for growers to obtain economic profitability. For this trait, it is known that plants yielding high tuber number generally produce smaller tubers (Silva et al., 2012). Both, number and size of tubers, directly influence marketable tuber yield (Silva et al., 2006). So, selection for balance between tuber number and tuber 
size, is important.

The objective of this work was to verify the performance of potato clones according to genotype values for tuber yield traits.

\section{MATERIAL AND METHODS}

The experiments were installed in Canoinhas $\left(26^{\circ} \mathrm{S}, 50^{\circ} \mathrm{W}, 839 \mathrm{~m}\right.$ altitude), and in Pelotas $\left(31^{\circ} \mathrm{S}, 52^{\circ} \mathrm{W}, 50\right.$ $\mathrm{m}$ altitude), with planting dates at end August. Eleven advanced potato clones of Embrapa's breeding program were evaluated and compared to commercial check cultivars Agata and Asterix.

A randomized complete block design with four replications was used. Plots were composed of two 3.5-meter rows, 10 plants each. Seed tubers (type II: diameter between 40 and $50 \mathrm{~mm}$ ), after stored during eight months in cold chamber $\left(4.0 \pm 0.5^{\circ} \mathrm{C}\right)$, were used. Planting spacings were 75 $\mathrm{cm}$ between rows and $35 \mathrm{~cm}$ within plants. As fertilizer the commercial formula 5-30-10 of N-P-K was used, $2.5 \mathrm{t} \mathrm{ha}^{-1}$. Cultural and phytosanitary treatments followed recommendations for the region (Pereira, 2010). After plant senescence, approximately 110 days after planting, crops were harvested.

The evaluated yield component traits were number of marketable tubers plot $^{-1}$, (diameter above $45 \mathrm{~mm}$ ); total number of tubers plot $^{-1}$; mass of marketable tubers $\left(\mathrm{kg} \mathrm{plot}^{-1}\right)$; total mass of tubers $\left(\mathrm{kg} \mathrm{plot}^{-1}\right)$; and, average tuber weight ( $\mathrm{g}$ tuber $^{-1}$ ), obtained by dividing the total mass of tubers by total number of tubers.
The number of tubers was converted to number of tubers $\mathrm{ha}^{-1} / 1000$ and yield traits in $\mathrm{tha}^{-1}$.

Joint deviance analysis for each trait was performed to ascertain the significance of effects, and for the evaluation of genotype GE interaction using the REML/BLUP method (Henderson, 1975).

For joint deviance analysis for both environments, the statistical model used was:

$$
y=X_{r}+Z_{g}+W_{i}+e
$$

Where $y$ is the data vector, $r$ is the vector of the replication effects (assumed to be fixed) added to the general average, and all replicates of all environments, $g$ is the vector of genotypic effects (assumed to be random), $i$ is the vector of GE interaction effects (random), and the error vector (random). $X, Z$, and $W$ are the matrices of incidence that relate effects of $r, g$, and $i$ to the $y$ vector, respectively (Resende, 2002a).

SELEGEN software (Resende, 2002b) was used to perform these analyzes.

\section{RESULTS AND DISCUSSION}

The deviance analysis revealed significant differences $(\mathrm{p}<0.01)$ between genotypes for all evaluated traits (Table 1). There was also a significant effect of GE interaction for all traits, indicating that genotype performance was not similar at both sites (Table 1).

Phenotypic coefficients of variation (CV) were lower for tuber number and total tuber yield, and average tuber weight, ranging from 10.82 to $11.50 \%$. For marketable tuber number and marketable tuber yield, CVs were higher (23.25\% and $24.35 \%$, respectively). Considering that tuber yield is a quantitative trait, which usually suffers a great environmental influence (Silva et al., 2006), the precision of these experiments was adequate. $\mathrm{CV}$ values of these experiments are similar to those reported by Silva et al. (2006), which ranged from 17.31 to $21.03 \%$ for yield (total tuber mass), total number of tubers and average tuber mass, and to those verified by Bisognin et al. (2008), with values varying between 16.19 and $25.60 \%$, for the yield traits of potato clones of different sizes. Likewise, Costa et al. (2007) found CVs between 22.70 and $18.30 \%$, for total tuber yield and total tuber number, respectively.

The effects of genetic order on the phenotype observed by magnitudes of genotypic variances, however, indicate that selection based on these traits would be efficient (Table 1).

The adequacy of experimental precision was also confirmed by the selective accuracy, which was higher than $70 \%$ for most traits, except for the marketable tuber mass $(63 \%)$ (Table 1). According to Resende (2002a), the value of selection accuracy, which is the square root of average heritability, evidences precision in inferences of genotypic values, indicating suitability of the experimental conduction for identification of superior genotypes.

GE interaction was of great importance for all traits, as observed

Table 1. Values of the likelihood ratio test (LRT) of the joint deviance analysis for yield traits, of 13 potato genotypes evaluated in Pelotas and Canoinhas in spring 2014. Canoinhas, Embrapa, 2018.

\begin{tabular}{lccccc}
\hline Effect & MTN & MTY & TTN & TTY & ATW \\
\hline Genotype $^{1}$ & $66.78^{*}$ & $89.62^{*}$ & $90.45^{*}$ & $129.14^{*}$ & $80.00^{*}$ \\
Genotype x environment $^{1}$ & $31.49^{*}$ & $54.00^{*}$ & $38.94^{*}$ & $80.73^{*}$ & $40.65^{*}$ \\
Coef. determination of interaction $_{\text {Genetic correlation between environments }}$ & 0.45 & 0.59 & 0.41 & 0.59 & 0.49 \\
Acuracy in the selection & 0.37 & 0.26 & 0.49 & 0.33 & 0.37 \\
Coeficient of variation (\%) & 0.71 & 0.63 & 0.79 & 0.70 & 0.71 \\
General mean & 23.25 & 24.35 & 10.82 & 11.50 & 11.18 \\
\hline
\end{tabular}

${ }^{1}$ LRT values; * significant at $\mathrm{P}<0.01$ by the $\chi^{2}$ test with 1 degree of freedom. $\mathrm{MTN}=$ marketable tuber number $\left(\mathrm{ha}^{-1} / 1000\right)$; MTY $=$ marketable tuber yield $\left(\mathrm{t} \mathrm{ha}^{-1}\right)$; TTN $=$ total tuber number $\left(\mathrm{ha}^{-1} / 1000\right)$; TTY $=$ total tuber yield $\left(\mathrm{t} \mathrm{ha}^{-1}\right)$; ATW= average tuber weight $\left(\mathrm{g}\right.$ tuber $\left.{ }^{-1}\right)$. 
Table 2. Estimates of predicted genetic $(g)$ and genotypic values $(u+g)$ for ${ }^{1}$ Pelotas, ${ }^{2}$ Canoinhas and ${ }^{3}$ joint for both environments, and estimates of mean genotypic value $(u+g+g$ em $)$ of 13 potato genotypes for total tuber number $\left(\mathrm{ha}^{-1} / 1000\right)$ and total tuber yield $\left(\mathrm{t}\right.$ ha $\left.{ }^{-1}\right)$, in spring 2014. Canoinhas, Embrapa, 2018.

\begin{tabular}{|c|c|c|c|c|c|c|c|}
\hline \multirow{2}{*}{ Genotype } & $g^{1}$ & $u+g^{1}$ & $g^{2}$ & $u+g^{2}$ & $g^{3}$ & $u+g^{3}$ & $u+g+g e m$ \\
\hline & \multicolumn{7}{|c|}{ Total tuber number } \\
\hline Agata (check) & -147.15 & 346.15 & -90.49 & 409.84 & -79.77 & 417.04 & 375.69 \\
\hline Asterix (check) & 74.52 & 567.82 & -34.86 & 465.47 & 13.31 & 510.13 & 517.03 \\
\hline C2519-12-06 & -43.94 & 449.36 & -54.60 & 445.73 & -33.08 & 463.73 & 446.59 \\
\hline F102-22-07 & -84.78 & 408.52 & -86.89 & 413.44 & -57.63 & 439.18 & 409.31 \\
\hline F189-09-06 & -96.44 & 396.85 & 106.01 & 606.34 & 3.22 & 500.03 & 501.70 \\
\hline F208-01-06 & -91.06 & 402.24 & -86.90 & 413.43 & -59.74 & 437.07 & 406.11 \\
\hline F22-01-08 & 132.86 & 626.15 & -81.96 & 418.37 & 17.08 & 513.89 & 522.74 \\
\hline F23-11-06 & 171.45 & 664.75 & 23.02 & 523.35 & 65.28 & 562.09 & 595.92 \\
\hline F23-24-06 & 77.22 & 570.51 & 111.84 & 612.17 & 63.47 & 560.28 & 593.18 \\
\hline F31-05-08 & -68.17 & 425.12 & -30.81 & 469.52 & -33.23 & 463.58 & 446.36 \\
\hline F32-02-06 & 117.15 & 610.45 & 243.75 & 744.08 & 121.16 & 617.98 & 680.77 \\
\hline F32-11-06 & 51.19 & 544.49 & 66.09 & 566.42 & 39.37 & 536.19 & 556.59 \\
\hline \multirow[t]{2}{*}{ F38-03-07 } & -92.85 & 400.44 & -84.21 & 416.12 & -59.44 & 437.37 & 406.57 \\
\hline & \multicolumn{7}{|c|}{ Total tuber yield } \\
\hline Agata (check) & -7.12 & 11.20 & -14.67 & 17.84 & -5.52 & 19.90 & 14.41 \\
\hline Asterix (check) & 2.38 & 20.70 & -9.63 & 22.89 & -1.82 & 23.60 & 21.79 \\
\hline C2519-12-06 & -1.85 & 16.47 & -7.91 & 24.60 & -2.47 & 22.95 & 20.49 \\
\hline F102-22-07 & -0.67 & 17.65 & 7.46 & 39.98 & 1.71 & 27.13 & 28.83 \\
\hline F189-09-06 & -3.98 & 14.34 & 10.89 & 43.41 & 1.73 & 27.15 & 28.86 \\
\hline F208-01-06 & -6.46 & 11.86 & -5.55 & 26.96 & -3.05 & 22.37 & 19.33 \\
\hline F22-01-08 & 7.53 & 25.85 & -8.98 & 23.54 & -0.34 & 25.08 & 24.75 \\
\hline F23-11-06 & 3.31 & 21.63 & 4.83 & 37.35 & 2.06 & 27.48 & 29.53 \\
\hline F23-24-06 & 6.06 & 24.38 & 7.16 & 39.68 & 3.35 & 28.77 & 32.10 \\
\hline F31-05-08 & 0.58 & 18.90 & 4.50 & 37.02 & 1.28 & 26.70 & 27.97 \\
\hline F32-02-06 & 5.33 & 23.65 & 20.02 & 52.53 & 6.41 & 31.82 & 38.19 \\
\hline F32-11-06 & 0.61 & 18.93 & 4.41 & 36.92 & 1.27 & 26.68 & 27.94 \\
\hline F38-03-07 & -5.72 & 12.60 & -12.54 & 19.97 & -4.62 & 20.79 & 16.20 \\
\hline
\end{tabular}

by the proportion of variance of GE interaction on total phenotypic variance. It was calculated by the coefficient of determination of the interaction, which was close to $50 \%$ for most traits, and by genetic correlation between environments, which was reduced, varying from 0.26 for marketable tuber yield to 0.49 for total tuber number (Table 1). The low values of accuracy in selection based on joint analysis and genetic correlation between environments reinforce the importance of studying GE interaction to maximize gains in clone selection.
Both, tuber number and tuber size, directly influence marketable tuber yield (Silva et al., 2006). Therefore, it is important in selection process to find the balance between tuber number and tuber size. For total tuber number, the clones with highest estimates of free genetic values of the interaction for Pelotas and Canoinhas were F23-11-06, F23-24-06, F32-02-06 and F32-11-06, contributing with increases to general mean of $65.28,63.47,121.16$ and 39.37 tubers ha-1/1000, respectively, (Table 2). Predicted genotypic values, that is, the general mean capitalized by genetic values in selection of these genotypes, varied between 536.19 and 617.98 tubers ha ${ }^{-1} / 1000$. Cultivar Agata (check) had the worst performance for this trait, presenting the lowest genetic value. For this trait, 'Asterix' (check) and F22-01-08 were adapted specifically to Pelotas, and F189-09-06 to Canoinhas. Considering the average interaction of environments $(\mathrm{u}+\mathrm{g}+\mathrm{gem})$, which is equivalent to the average genotypic value of the two locations considering the interaction, clones F23-11-06, F2324-06, F32-02-06, and F32-11-06 had the highest values, 595.92, 593.18, 
Table 3. Estimates of predicted genetic $(g)$ and genotypic values $(u+g)$ for ${ }^{1}$ Pelotas, ${ }^{2}$ Canoinhas and ${ }^{3}$ joint for both environments, estimates of genotypic value $(u+g+$ gem $)$, of 13 potato genotypes for marketable tuber number $\left(\mathrm{ha}^{-1} / 1000\right)$ and marketable tuber yield $\left(\mathrm{t}\right.$ ha $\left.{ }^{-1}\right)$, in spring 2014. Canoinhas, Embrapa, 2018.

\begin{tabular}{|c|c|c|c|c|c|c|c|}
\hline \multirow{2}{*}{ Genotype } & $g^{1}$ & $u+g^{l}$ & $g^{2}$ & $u+g^{2}$ & $g^{3}$ & $u+g^{3}$ & $u+g+g e m$ \\
\hline & \multicolumn{7}{|c|}{ Marketable tuber number } \\
\hline Agata & -27.36 & 52.16 & -64.18 & 49.49 & -25.68 & 70.91 & 49.44 \\
\hline Asterix & -12.07 & 67.45 & -47.66 & 66.01 & -16.58 & 80.01 & 66.14 \\
\hline C2519-12-06 & -3.62 & 75.90 & -38.72 & 74.94 & -11.61 & 84.99 & 75.28 \\
\hline F102-22-07 & 24.14 & 103.66 & 40.78 & 154.44 & 18.36 & 114.95 & 130.30 \\
\hline F189-09-06 & -7.65 & 71.88 & 44.35 & 158.02 & 9.74 & 106.34 & 114.48 \\
\hline F208-01-06 & -13.28 & 66.25 & -0.31 & 113.36 & -4.09 & 92.51 & 89.09 \\
\hline F22-01-08 & 41.44 & 120.97 & -44.53 & 69.14 & 0.40 & 96.99 & 97.33 \\
\hline F23-11-06 & -24.14 & 55.38 & 17.11 & 130.77 & -2.63 & 93.96 & 91.76 \\
\hline F23-24-06 & 20.12 & 99.64 & 11.30 & 124.96 & 9.14 & 105.73 & 113.37 \\
\hline F31-05-08 & -1.21 & 78.32 & 34.53 & 148.19 & 9.01 & 105.61 & 113.15 \\
\hline F32-02-06 & 37.02 & 116.54 & 70.26 & 183.92 & 30.24 & 126.84 & 152.13 \\
\hline F32-11-06 & -6.44 & 73.09 & 22.92 & 136.58 & 4.28 & 100.88 & 104.46 \\
\hline \multirow[t]{2}{*}{ F38-03-07 } & -26.96 & 52.56 & -45.87 & 67.79 & -20.59 & 76.01 & 58.79 \\
\hline & \multicolumn{7}{|c|}{ Marketable tuber yield } \\
\hline Agata & -2.44 & 4.22 & -10.05 & 6.31 & -2.69 & 8.83 & 5.12 \\
\hline Asterix & -1.17 & 5.49 & -8.47 & 7.90 & -2.06 & 9.46 & 6.62 \\
\hline C2519-12-06 & -0.42 & 6.24 & -6.29 & 10.08 & -1.42 & 10.09 & 8.13 \\
\hline F102-22-07 & 2.25 & 8.91 & 11.71 & 28.07 & 2.99 & 14.50 & 18.63 \\
\hline F189-09-06 & -0.74 & 5.92 & 6.81 & 23.18 & 1.26 & 12.78 & 14.52 \\
\hline F208-01-06 & -2.29 & 4.37 & -0.76 & 15.61 & -0.69 & 10.82 & 9.86 \\
\hline F22-01-08 & 3.77 & 10.43 & -6.74 & 9.62 & -0.54 & 10.97 & 10.22 \\
\hline F23-11-06 & -1.91 & 4.75 & 2.79 & 19.15 & 0.14 & 11.66 & 11.85 \\
\hline F23-24-06 & 2.76 & 9.42 & 1.12 & 17.49 & 0.88 & 12.39 & 13.60 \\
\hline F31-05-08 & 0.61 & 7.26 & 5.64 & 22.00 & 1.33 & 12.84 & 14.68 \\
\hline F32-02-06 & 2.72 & 9.37 & 10.94 & 27.30 & 2.94 & 14.45 & 18.50 \\
\hline F32-11-06 & -0.68 & 5.98 & 2.19 & 18.56 & 0.30 & 11.82 & 12.24 \\
\hline F38-03-07 & -2.46 & 4.20 & -8.87 & 7.49 & -2.44 & 9.07 & 5.70 \\
\hline
\end{tabular}

680.77 and 556.59 tubers $\mathrm{ha}^{-1} / 1000$, respectively. In addition to high genetic value, these clones presented good performance for the environmental conditions considered in the calculation of the GE interaction.

For the best performing genotypes, a very similar situation was observed for total tuber yield and total tuber number, being F102-22-07 the only exception (Table 2). This clone presented a positive value for tuber yield in Canoinhas, but this was not true for total tuber number. Likewise, clone F32-11-06 in Pelotas did not stand out for total yield as much as for total tuber number. For total yield, the best clones were F2311-06, F23-24-06 and F32-02-06, with mean genotypic values considering the interaction of $29.53,32.10$ and $38.19 \mathrm{t} \mathrm{ha}^{-1}$, respectively, well above the average of the experiments $(25.42$ $\left.\mathrm{t} \mathrm{ha}^{-1}\right)$ and to expected mean of checks $\left(18.10 \mathrm{t} \mathrm{ha}^{-1}\right)$. Therefore, for total tuber number and total yield, F23-11-06, F2324-06 and F32-02-06 stood out from the other clones, both eliminating the GE interaction effect and considering its effects.

For marketable tuber number and marketable tuber yield, clones with highest genetic values for both tested locations were F102-22-07 and F3202-06, with estimated marketable tuber number of 130.30 and 152.13 tubers $\mathrm{ha}^{-1} / 1000$, and marketable tuber yield of 18.63 and $18.50 \mathrm{t} \mathrm{ha}^{-1}$, respectively, considering the interaction $(u+g+g e m)$ (Table 3). These yield values are on average $46.20 \%$ and $61.25 \%$ above the overall mean of the experiment for marketable tuber number and marketable tuber yield characters. Clones F22-01-08 and F23-24-06 presented higher marketable yields, 
Table 4. Estimates of predicted genetic $(g)$ and genotypic $(u+g)$ values for ${ }^{1}$ Pelotas, ${ }^{2}$ Canoinhas and ${ }^{3}$ joint for both environments, estimates of the mean genotypic value $(u+g+g e m)$, of 13 potato genotypes for average tuber weight $\left(\mathrm{g}\right.$ tuber $\left.{ }^{-1}\right)$, in spring 2014. Canoinhas, Embrapa, 2018.

\begin{tabular}{lccrcccc}
\hline Genotype & $\boldsymbol{g}^{\mathbf{1}}$ & $\boldsymbol{u}^{+\boldsymbol{g}^{\mathbf{1}}}$ & $\boldsymbol{g}^{\mathbf{2}}$ & $\boldsymbol{u}+\boldsymbol{g}^{\mathbf{2}}$ & $\boldsymbol{g}^{\mathbf{3}}$ & $\boldsymbol{u}^{+\boldsymbol{g}^{\mathbf{3}}}$ & $\boldsymbol{u + g + g e m}$ \\
\hline Agata & -4.18 & 32.86 & -19.31 & 45.59 & -6.44 & 44.53 & 38.98 \\
Asterix & -0.66 & 36.38 & -14.41 & 50.49 & -4.11 & 46.86 & 43.31 \\
C2519-12-06 & -0.21 & 36.83 & -9.09 & 55.81 & -2.54 & 48.43 & 46.24 \\
F102-22-07 & 6.07 & 43.11 & 31.33 & 96.23 & 10.24 & 61.21 & 70.05 \\
F189-09-06 & -0.72 & 36.32 & 5.76 & 70.66 & 1.37 & 52.34 & 53.52 \\
F208-01-06 & -6.82 & 30.22 & 0.86 & 65.76 & -1.68 & 49.29 & 47.84 \\
F22-01-08 & 3.83 & 40.87 & -6.64 & 58.26 & -0.74 & 50.23 & 49.60 \\
F23-11-06 & -3.97 & 33.07 & 6.45 & 71.35 & 0.65 & 51.62 & 52.17 \\
F23-24-06 & 5.24 & 42.28 & 1.02 & 65.93 & 1.75 & 52.72 & 54.23 \\
F31-05-08 & 7.19 & 44.23 & 14.15 & 79.05 & 5.87 & 56.84 & 61.91 \\
F32-02-06 & 1.50 & 38.54 & 5.81 & 70.72 & 2.01 & 52.98 & 54.71 \\
F32-11-06 & -2.23 & 34.81 & 0.10 & 65.01 & -0.60 & 50.38 & 49.86 \\
F38-03-07 & -5.05 & 31.99 & -16.02 & 48.88 & -5.78 & 45.19 & 40.20 \\
\hline
\end{tabular}

specifically for Pelotas, while F102-2207 and F32-02-06 were more adapted to Canoinhas.

For average tuber weight, which correlates with average tuber size, higher genetic values were observed for both locations, for clones F102-22-07 and F31-05-08, with mean genotypic values, considering GE interaction, of 70.05 and $61.89 \mathrm{~g}^{\text {tuber }}{ }^{-1}$, respectively (Table 4).

Thus, considering all tuber yield traits, clones that most stood out positively for the two locations were F102-22-07 and F32-02-06. Although not presenting high total tuber yield, clone F102-22-07 had high marketable tuber yield and high average tuber weight. On the other hand, Clone F3202-06, although not having the highest averages tuber yield, showed high total and marketable tuber yield.

Considering marketable tuber yield, $5.87 \mathrm{t} \mathrm{ha}^{-1}$ was the mean of check cultivars Agata and Asterix, cultivars widely grown in the country. Means for check cultivars are similar to those reported by Silva et al. (2016) in Canoinhas, based on a two-year experiment, observed marketable tuber yield of 7.54 and $9.47 \mathrm{t} \mathrm{ha}^{-1}$ for 'Agata' and 'Asterix', respectively. Also Silva et al. (2016b), found averages of 5.06 and $7.14 \mathrm{t} \mathrm{ha}^{-1}$ in Pelotas, for cultivars Agata and Asterix, respectively.
The mean marketable tuber yield of clones F102-22-07 and F32-02-06 was $18.56 \mathrm{t} \mathrm{ha}^{-1}$, therefore, well above means observed for the check cultivars. This superiority indicates potential of these clones to be released in the future as new cultivars, after proving their performance in further yield trials to be carried out in different potato growing regions of the country.

The clones F102-22-07 and F32-0206 stood out positively for tuber yield. F102-22-07 showed high marketable tuber yield and average tuber weight, while clone F32-02-06 exhibited high marketable and total tuber yield. The superiority of these advanced clones in relation to the check cultivars, suggests their potential to be evaluated in other environments, aiming their release as new cultivars.

\section{REFERENCES}

BORGES, V; FERREIRA, PV; SOARES, L; SANTOS, GM; SANTOS, AMM. 2010. Seleção de clones de batata-doce pelo procedimento REML/BLUP. Acta Scientiarum Agronomy 32: 643-649.

BISOGNIN, DA; MÜLLER, DR; STRECK, NA; ANDRIOLO, JL; SAUSEN, D. 2008. Desenvolvimento e rendimento de clones de batata na primavera e no outono. Pesquisa Agropecuária Brasileira 43: 699-705.

COSTA, LC; BISOGNIN, DA; ANDRIOLO, JL; RITTER, CEL; BANDINELLI, MG. 2007.
Identificação de clones de batata com potencial para mesa e adaptados para os cultivos de outono e primavera do Rio Grande do Sul. Ciência e Natura 29: 93-104.

CRUZ, CD; REGAZZI, AJ; CARNEIRO, PCS. 2012. Modelos biométricos aplicados ao melhoramento genético. Viçosa: Editora UFV. 514p.

GADUM, J; PINTO, CABP; RIOS, MCD. 2003. Desempenho agronômico e reação de clones de batata (Solanum tuberosum L.) ao PVY. Ciência e Agrotecnologia 27: 1484-1492.

HENDERSON, CR. 1975. Best linear estimation and prediction under a selection model. Biometrics 31: 423-447.

KOOMAN, PL; RABBINGE, R. 1996. An analysis of the relation between dry matter allocation to the tuber and earliness of a potato crop. Annals of Botany 77: 235-242.

MENEZES, CB; PINTO, CABP; NURMBERG, PL; LAMBERT, ES. 2001. Combining ability of potato genotypes for cool and warm seasons in Brazil. Crop Breeding and Applied Biotechnology 1: 145-157.

MOHAMMADI, R; HAGHPARAST, R; AGHAEE, M; ROSTAEE, M; POURDAD, SS. 2007. Biplot analysis of multi-environment trials for identification of winter wheat megaenvironments in Iran. World Journal of Agricultural Sciences 3: 475-480.

PEREIRA AS (org). 2010. Produção de batata no Rio Grande do Sul. Sistema de Produção, 19. Pelotas: Embrapa Clima Temperado. 95p.

PINTO, CABP; TEIXEIRA, AL; NEDER, DG; ARAÚJO, RR; SOARES, ARO; RIBEIRO, GHMR; LEPRE, AL. 2010. Potencial de clones elite de batata como novas cultivares para Minas Gerais. Horticultura Brasileira 28: 399-405.

RESENDE, MDV. 2002a. Genética biométrica e estatística no melhoramento de plantas perenes. Brasília: Embrapa Informação Tecnológica. $975 \mathrm{p}$ 
RESENDE, MDV. 2002b. Software SelegenREML/BLUP. Curitiba: Embrapa Florestas. $67 \mathrm{p}$.

SILVA, GO; SOUZA, VQ; PEREIRA, AS; CARVALHO, FIF; FRITSCHE-NETO, R. 2006. Early generation selection for tuber appearance affects potato yield components. Crop Breeding and Applied Biotechnology
6: 73-78.

SILVA, GO; CASTRO, CM; TERRES, LR; ROHR, A; SUINAGA, FA; PEREIRA, AS. 2012. Desempenho agronômico de clones elite de batata. Horticultura Brasileira 30: 557-560. SILVA, GO; CARVALHO, ADF; SILVA, SZ; PONIJALEKI, RS; SILVA, AS. 2016a. Desempenho genotípico de clones de batata via modelos mistos. Revista Brasileira de Ciências Agrárias 11: 259-266.

SILVA, GO; PEREIRA, AS; AZEVEDO, FQ; CARVALHO, ADF. 2016. Avaliação de clones de batata para caracteres de rendimento e qualidade de fritura. Revista Latinoamericana de la Papa 20: 37-44. 